\title{
A BIOETHICAL PERSPECTIVE ON ACCEPTABLE-RISK CRITERIA FOR NUCLEAR-WASTE MANAGEMENT $\therefore$
}

M. N. Maxey

July 15, 1977

\section{MASTER}

Prepared for U.S. Energy Research \& Development Administration under contract No. W-7405-Eng-48
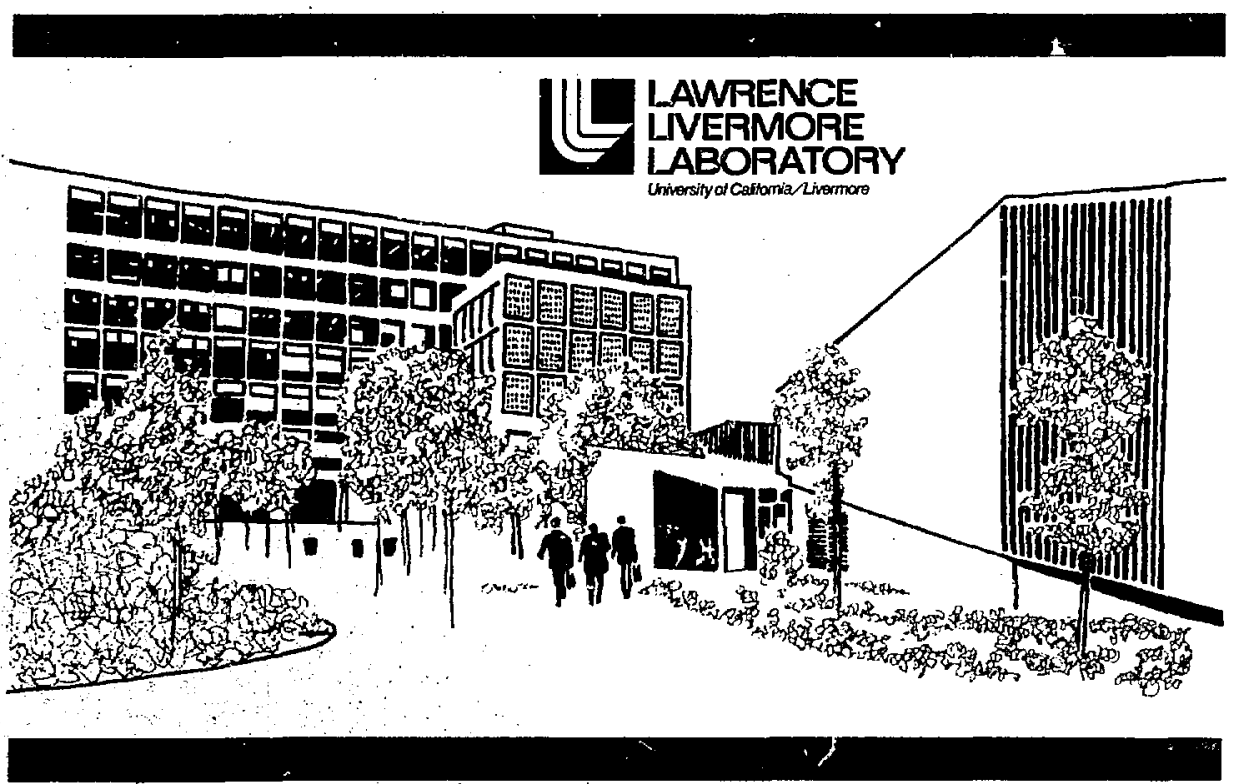


\section{NOTICE}

This report was prepared at an sccount of work monsared by the United States Government. Neither the United States nor the United States Energy Research 4 Development Adminisintion, nor any of their employees, not any of their contractors, nubcontractors, or their employeen, makes any warranty, oxprean or impled, or aswimes any legal liability or responsibility for the cccuracy, completenes: or usefulness of any information, apperatus, product or process dieclosed, or represents thit its uxe would not infingo privately-owned rights.

\section{NOTICE}

Reference to a company or product name does not inply approval or recommendation of the product by the University of Calliforniz or the U.S. Energy Research a Development Adminlstration to the exclusion of others thut may be suitable.

Printed in the United States of America Avallable from

National Technical Information Service

U.S. Department of Commerce

\$285 Port Royal Rogd

Springfield, VA 22161

Price: Printed Copy $\$$; Microfiche $\$ 3.00$

\begin{tabular}{|c|c|c|c|}
\hline Pag Rang & $\begin{array}{c}\text { Domentic } \\
\text { Price }\end{array}$ & Page Range & $\begin{array}{c}\text { Domestle } \\
\text { Pijca }\end{array}$ \\
\hline $001-025$ & s 3.50 & $326-350$ & 10.00 \\
\hline $026-050$ & 4.00 & $351-375$ & 10.50 \\
\hline $051-075$ & 4.50 & $376-400$ & 10.75 \\
\hline $076-100$ & 5.00 & $401-425$ & $\$ 1.00$ \\
\hline $101-125$ & 5.50 & $426-450$ & 11.75 \\
\hline $126-150$ & 6.00 & $451-475$ & 12.00 \\
\hline $153-175$ & 6.75 & $476-500$ & 12.50 \\
\hline $176-200$ & 7.50 & $501-525$ & 12.75 \\
\hline $201-225$ & 7.75 & $526-550$ & 13.00 \\
\hline $226-250$ & 8.00 & $551-575$ & 1350 \\
\hline $251-275$ & 9,00 & $576-600$ & 13.75 \\
\hline $276-300$ & 9.25 & 601-up & $*$ \\
\hline $301-325$ & 9.75 & & \\
\hline
\end{tabular}

"Add $\$ 250$ for exch addilonal 100 page trerement from 601 to 1,000 perse: add \$4SO for each additional t00 page increment over 1,000 pages. 


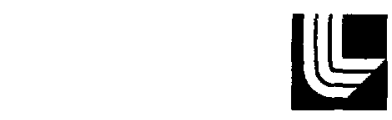

\section{LAWRENCE LIVERMORE LABORATORY}

University of Cahtomia Livermore, Calfornia ' 94550

\section{A BIOETHICAL PERSPECTIVE ON ACCEPTABLE-RISK CRITERIA FOR NUCLEAR-WASTE MANAGEMENT}

M. N. Maxey, University of Detroit;

prepared under consultant agreement with Lawrence Livermore Laboratory

for work sponsored by the U.S. Nuclear Regulatory Commission

MS date: July 15, 1977

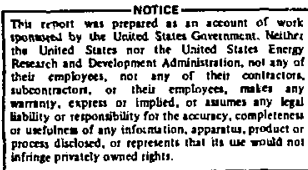




\section{Foreword}

The U.S. Nuclear Regulatory Commission has contracted Lawrence Livermore Laboratory to pruvide "Technical Support in the Development of NuclearWaste Management Criteila." Part of this effort involves development of acceptable-rlsk criterla for nuclearwaste-management operations. Such operations inevitably involve some risk to man and his environment. Indeed, no industrial operation can be devoid of all risk. The object, therefore, must be to determine an acceptable level of risk that can serve as a guideline for operational design and analysis.

Nuclear-waste management is a serious concern. Its hazards may be extremely severe. In addition, due to the extensive time required for radioactive decay of certain nuclides, it may leave a legacy of harm to future populations. Alvin Weinberg has characterized this latter situation as a "Faustian bargain," in which current generations reap the benefits of nuclear energy while leaving hazards for future gienerations to cope with.

Recognizing that such considerations transcend technologtcal comprehension, we believe that a scholarly study of the moral and ethical implications might contribute to our understanding of the problem. Such studies might best be performed by those with professional expertise in these areas of inquiry.

With this objective, Dr. Margaret Maxey was requested to perform this study. Dr. Maxey is Assoclate Professor of Bioethics at the University of Detrult. She has served as an ethical consultant on "The Plutonium Economy" to the National Council of Churches and has served on the Board of Directors of the National Center for Energy Education.

In conducting and reporting a study of this nature, it is extremely difflcult, if not impossible, to avoid incorporating subjective materia1. This report attempts to present a moral and ethlcal perspective on nuclear-waste-management hazards and to encourage further academic inquiry into questions related to societal acceptance or rejection of technological risk. An understanding and possible resolution of these questions would greatly assist the technical communfty in dealing with such issues.

Jerry J. Cohen

Waste Management Program Jawrence Livermore Laboratory 
SPECIFICATIONS FOR ENDEVCO ACCELEROMETER

MODEL NO. $2262 \mathrm{C}-25$ (range $\pm 25 \mathrm{~g}$ )

Dynanic

Rated range

-25 to $+25 \mathrm{~g}$

Useful range

-50 to $+50 \mathrm{~g}$

Overrarge limiting

\pm 60 to $\pm 150 \mathrm{~g}$

Sensitivity (at $1.0 .00 \mathrm{~V} \mathrm{dc}$ )

$10 \mathrm{mV} / \mathrm{g}$, nominal

Mounted natural frequency

$2500 \mathrm{~Hz}$, nominal

Frequency response

$\pm 5 \%, 0$ to $750 \mathrm{~Hz}$ at $75^{\circ} \mathrm{F}\left(24^{\circ} \mathrm{C}\right)$;

$-35 \%$ ! $+10 \%$, nominal ai $0^{\circ} \mathrm{F} / 200^{\circ} \mathrm{F}$ and

$750 \mathrm{~Hz}$.

Damping ratio

0.7 nominal at $75^{\circ} \mathrm{F}$

Transverse sensitivity

3\% maximum

Linearity and hysteresis

$\pm 1 \%$ of reading, maximum, to $\pm 25 \mathrm{~g}$;

$\pm 3 \%$ of reading, nominal, to $\pm 50 \mathrm{~g}$.

Thermal sensitivity shift

$-4 \% / 0 /-9 \%$, nominal, at $0^{\circ} / 75^{\circ} / 200^{\circ} \mathrm{F}$

\section{Electrical}

Excitation

Input resistance (at $75^{\circ} \mathrm{F}$ )

$10.00 \mathrm{~V} \mathrm{dc}$

Output resistance (at $75^{\circ} \mathrm{F}$ )

$1000 \Omega$, nominal

Zero measurand output

Thermal zero shift

Insulation resistance

$1000 \Omega$, nominal

$\pm 25 \mathrm{mV}$ maximum at $10.00 \mathrm{~V}$ and $75^{\circ} \mathrm{F}$

$\pm 15 \mathrm{mV}$, maxtmum at $0^{\circ} \mathrm{F}$ and $+200^{\circ} \mathrm{F}$,

reference $75^{\circ} \mathrm{F}$

$100 \mathrm{M} \Omega$, mintmum

\section{Physica1}

Weight

Material

Sersing elements

Mounting

Electrical connection

$28 \mathrm{~g}$, nominal, plus cable at $6 \mathrm{~g} / \mathrm{ft}$

Stainless steel

Plezite Type P-11

Tapped hole for 10-32 $\times 1 / 8^{\prime \prime}$ stud

Recommended mounting torque: $18 \mathrm{in}$.- Ib

Integral 6-pin connector 


\section{A BIOETHICAL PERSPECTIVE ON ACCEPTABLE-RISK CRITERIA FOR NUCLEAR-WASTE MANAGEMENT}

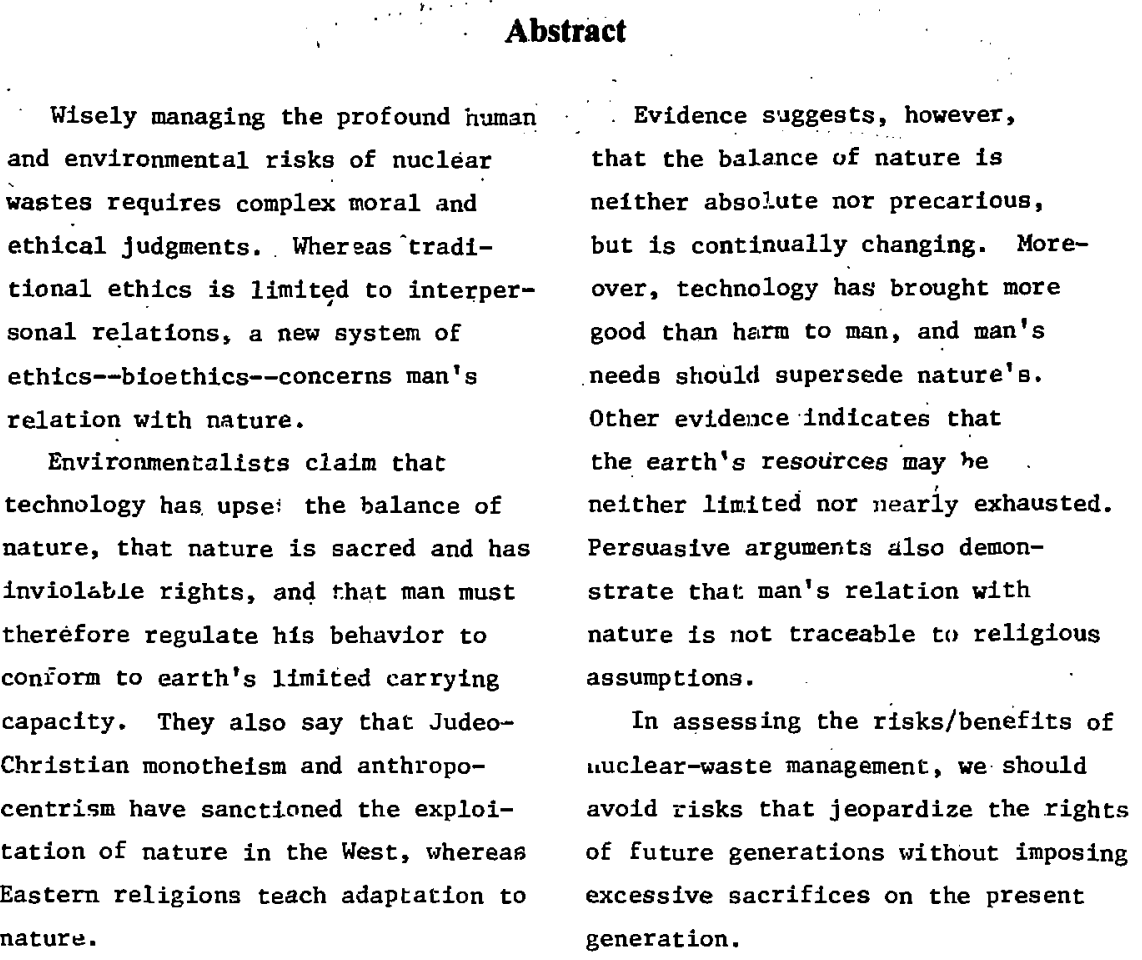

\section{Introduction}

Criteria for acceptable sucletal risks assoclated with managing radioactive wastes will become increasingly clear as these criteria reflect an exhaustive formal method that exhibits:

- carefully measured or modelled rfsks compared against "reference acceptable risk levels,"
- positive systematic control of cisks,

- public confidence that responstble institutions can and will Improve safety (i.e., diminish rfsks). 1

Confidence in this expectation appears to be grourided in a certain 
kind of faith, appropriately identifled as a "managerial falth." The success of advanced technology in the modern world attests to the remarkable success of this faith. It has gravitated around the notion that "the most important things about Iife are ultimately manageable"; by extending the division of labor, seemingly intractable problems can be reduced to manageable proportions with the result tinat "men are chus empowered to deal with their condition." ${ }^{2}$ The pragmatic success of a managerial faith contrasts sharply, however, with that of theologians of other faiths, who have believed that such matters were ineffable, unalterable, and beyond human powers to divine, much less control.

Despite an undeniable success, the recoro of historical experience amply attests that the human spirit is restlessly at odds with a managerial faith. On the one hand, it is altogether understandable that management and long-term planning required by advanced technologfes should ceaselessly generate L.le urge to establish a predictable routine and to extend ever-wider control over uncertain consequences in a more total environment to make plans come true. On the other hand, it is likewise understandable that a human thirst for spontaneity and innovation, for creativity and adventure, should ceaselessly find ways to $\mathrm{cisrupt}$ the routines and alter the planning.

A misinterpretation of the conflict might lead a technologist to conclude that risk-taking is inimical to the human spirtt. Nothing could be further from the truth. Life without spontaneity, adventure, and risk-li:e totally ranaged, controlled, and predictablem-is devold of human interest or attraction. Criteria for the acceptability of risk should include a more comprehensive perspective on our common human condition, seen as a point of depiarture from the. past and as a set of real possibilities for the future.

In the interest of bringing some clarity to that perspective, this . study proposes to examine our common human condition as it relates to acceptable-risk criterla by exploring answers to three general questions:

(1) What basic ethical issues are raised by the values mankind has expressed through past technological developments in general, and present nuclear technology in particular?

(2) What historical influence have major religious perspectives exerted on assumptions underlying our current antitechnology, environmentalcrisis mentality? 
(3) What is our general obligation to future generations, and how does it relate to the acceptability of risks associated with nuclear fuel and radioactive waste?

\section{Technology, Environment, and Human Values: The Ethical Issues}

In an insightful essay, "Ethics, of Technology," Professor George Pickering suggests that the way to avoid the invidious ristinction between facts and values is to define values very simply as "those goods which depend for their fulftilment on human activity." And, he' says, if we wish to extricate ourselves from a world in which "the dignity of human action seems to be demeaned because inverition has incestuously become the mother of necessity," we must beg.,n to understand technology "not only as a highly integrated set of values but also as the single most powerful set of values entering into the constitution of the modern world. ${ }^{2}$

The fact that technology has become a questionable ictivity in our century does not imply that the question has been meaningfully formulated. It only implies that the issues raised by technology are not merely or primarily technical problems; they are soctal, political, ethical, and, In the . ofinion of some, moral.

The difficulty about defining technology-induced issues is typified by a recent statement about public ethics: when someone, announces that the public needs to define and consider "the ethicai and moral issues," the phrase usually "heralds the frustrated end of a discussion, or the beginning of a muddled argument." 3 This remark underscores the fundamental problem. It has never been more evident than in the way one alternative energy source--uranium-has become targeted.for elimination by certain environmentalists and political activists. In various public forums, they have argued that this energy source raises key issues which are not scientific or technical or economic, but moral and ethical. They go on to allege that experts in the nuclear energy field are profes: sionally unqualified for making ethical or moral judgments, because they can only make technical assessments and economic costr-benefit analyses. The inference is that only persons who are sctentifically filiterate and technically illInformed can be trușted to raise . moral and ethical issues for public 
debate. Presumably, science and technology are corrupting influences on the purity of moral judgments.

Ralsing issues in accord with such reasoning is problematic for at least three reasons: confusion between the terws morals and ethics, disagreement about the definltion of the human good, and differences between longrange goals and pressing social problems.

MORAI ISSUES VS ETHICAL ISSUES

The terms ethics and marals designate very different perspectives on human behavior. ${ }^{4}$ In philosophical literature, the word moral has two meanings: ( 1 ) the human capacity to make value judgments, and (2) human behavior consistent with ethical standards. According to the first usage, moral means the opposite of nonmoral, unmora1, or amoral, which denote a person who is unable to judge something to be right or good (an insane person). In the second usage, moral means the opposite of immoral, which denotes someone whose behavior is wrong or evil when judged by some accepted standard.

By contrast, ethics is generally regarded as a systematic philosophical analysis of moral value judgments and choices; it consists of theoretical. or rational interpretation of moral activity, whether individual or social. Normative ethics not only investigates moral theories, but also tries to establish criteria and principles that enjoin moral persons to adopt or refrain from certain judgments and conduct.

Moral judgments and ethical judgments about a disputed policy or pattern of behavior are neither $I_{n}$ practice nor in theory identical or interchangeable. Rather, these terms designate two distinct levels of discourse. 5

At the moral level, people operate within value codes derived from their social, religious, or ideological commitments. The function of these codes is to prescribe what one ought to do in particular cases. Customarily, people simply apply (In sliderule fashion) unexamined rules to specific problems of conduct or decision. But when conflicting values or circumstances lead one to ask whether a moral rule prescribing an action is really right, "the effect of such a question is to throw doubt upon the validity of the rules themselves." 5 The recognitior of alternatives to an action leads to a fundamental reconsideration of an entire code. As a result, one is compelled to move to the ethical level of discourse.

At the ethica! level, we re-examine uncritically accepted moral values, prlorlties, and prejudices. At this level, we are dealing with principles 
for maintaining reasonableness, for appraising value systems, far just1fying methods of decision-making, for balancing contilicts of interest.

Personal moral judgments must be put to the test of justification at this more comprehensive level of consideration. At a post-ethical level of discourse, the problem becomes discovering the purpose of being moral at a11 and/or the ultimate meaning system which one should use to justify proposed ethical criteria.

At both levels, the ethical issues raised are quite different from those raised by an unreflective moralist. As a definable characteristic, moralism is a deficiency that results from the persistent failure to recognize an ethical justification that is acceptable and undertakes responsibility for harmful social consequences of private moral judgments, however well-intentioned they may be.

\section{NEIGHBOR ETHICS VS TOTAL-SYSTEM} ETHICS (BIOETHICS)

A second problem of raising jissues is the confusion and disagreement over two different conceptions of how ethics should define the human good. According to Professor Hans Jonas, traditional ethics has assulued that the consequences of human action--hence human responsibility--are confined to the here and now, to known and intended effects. Therefore, it has lefined the human good as a moral imperative expressed in "neighbor values"--justice, truthteliing, freedom, respect for individual human rights, etc. ${ }^{6}$ This constellation of values is reflected in the current effort of government leaders to draw up ethical codes of behavior for public officlals, as well as for private citizens. So conceived, ethics is anthropocentric, with the non-human world of nature a neutral backdrop.

But sclence, technology, and a population explosion have drastically changed the causal scale of human activities, as well as our integration within nature's complex, delicate web. As a consequence, traditional neighbor ethics has become increasingly problematic, because it is too shorusighted and piecemeal in its definition of issues, goals, and human responsibility. Albert Schweitzer is often quoted in this regard: "The great fauit of all ethics hitherto has been that they belleved themselves to have to deal only with the relations of man to man." 7 Because of the awesome range and power with which human actions may affect the global environment for gcherations, a traditional neighbor ethic is simply inadequate Lu define criteria for the human good. 
Jonas urges us to realize the need for a new concept of ethics commensurate with the new scope of human action. He says that we must plan much further ahead with a "total-system" ethics shaped by a new set of imperatives. For example: "Act so that the effects of your action are compatible with the permanence of genulne human 1ife." or again, "In your present cholces, include the future wholeness of human persons among the objects of your decistons." 6 These imperatives presuppose an ability to acquire and disseminate an unprecedented degree of knowledge. A new total-system bloethics will raise issues from a perspective quite different from that of a traditional neighbor ethics. (For a discussion of total-system bioethics, see the appendix.)

\section{SOCIAL, ETHICS vS PUBLIC ETHICS}

Recognizing the need for a new concept and system of ethics is not enough. Changes in the scale of human action require not only a new genus of ethics, but also a new subspecies --"public ethics." ${ }^{3}$ Conventional soctal ethfes deals with the good or right ordering of human communities, and with shaping long-term changes in social policies. By contrast, public ethics must meet a different set of exigencies:
- It must deal with a precise problem requiring a particular public decision.

- This problem is pressing; it must be resolved soon.

- The decision to be made is neither intended nor expected to change the soctal order profoundly.

Current practitioners of public ethics have set three tasks for themselves. First, they propose to articulate the conflicting values that underlle a public concern, to transform them into an ethical argument that clarifles what can or cannot be justifled. Second, they try to identify policy options, and then defend or criticize them by appealing to justifying reasons. Finally, they rank these policy alternatives in some order of ethically preferable choices.

Ranking policy alternatives necessarily involves assessing risks vs benefits, weighing social and economic costs vs benefits, balancing a hypothetical vs a verifiable erosion of the quality of life. Far from being merely crass utilitarian tradeoffs, these exercises in hwman judgment are a necessity for responsible ethical decision-making.

Because it links ethics and politics, public ethics cannot indulge 
in the 1uxury of rarefied abstractions. To the extent that politics is "the art of the possible," public ethics endeavors to practice "the art of discerning the morally preferable among the practical possibilities." 8

From this review, it becomes easier to understand why the alleged mor 31 and ethical issues :aised by nuclear technology cause heated debate, if not muddled confusion, in the public mind. It remains to be seen how these conflicting terms relate to conflicting assessments of technology and 1 ts effect on the environment.

ETHICAL ISSUES RAISED BY ENVIRONMENTALIST ASSESSMENTS OF TECHNOLOGY

Some soclal historians regard the publication of The Silent Spring in $1962^{9}$ as a turning point in precip1tating what is popularly called the environmental crisis. Even a cursory reading of the environmentalist literature since then demonstrates that many persons hold the misconception that modern technology is alien to some pristine human condition. They refuse to consider seriously the evidence that mankind has from the beginning of recorded history developed an organic relationship with technology. It is an Imitation and extension of our own biological form and function, ${ }^{10}$ dependent for its being and fulfillment on human activity, ${ }^{2}$ and even a sacrament of liberation from mindless, subhuman drudgery and an opportunity for psychosocial development and maturity. 11

We cannot know, observes Pickering, whether those we call primitive men regarded their dxive toward technological development as a liberation from, or a fulfillment of, their inherited modes of existence. But we do know that the fundamental driving force throughout human history has been "a refusal to be dominated by the rest of nature." In our own decade of controversy, human beings have continued their dispute over what form that great refusal ought to take:

". . whether the domination of men by the rest of nature should be broken by magic, by religion, by art and craft, or by science and technology; . . . by discerning the rhythms of nature in order to oppose them or adopt them or manipulate them; by adopting the stance of participation of transcendence or exploitation."2

Paradoxically, our current technological development has become the most unifying yet the most divisive force in our common humanity.

At least since Earth Day 1970, we have been inundated with allegedly hard evidence that the deterioration of the human species and our natural envirourent is accelerating at an exponential rate, ${ }^{12}$ and that our 
only habitable planet has been raped and polluted by technological man, recklessly driven by rugged individualism and selfish greed. The damage inflicted has been portrayed as approaching eco-catastrophe.

Rivers and streams have allegedly been turned into sewers: Lake Erie is dead and Lake Michigan is fast dying. Environmentalists tell us that species of birds and animals are becoming extinct at a rapidly increasing rate: the last dodo died In 1689, with hundreds of other species dying since. According to Paul Ehr:ich and Garrett Hardin, our insecticides and weed poisons may have increased food supplies for an exponentially-Increasing population, but these toxic chemicals appear to have found their way up the food chain to enter and poison ourselves. The green revolution in underdeveloped countries seems to have had disastrous unforeseen consequences: soll depletion, followed by erosion and floods, not to mention the sustaining influence on the upward spiral of an already vast and starving population. More people to feed, clothe, and shelter means a greater consumption of energy and an eventual exhaustion of nonrenewable resources, as well as more pollution of the earth's atmosphere, soil, and water. 13

Technological interventions, pretending to be solutions, are indicted for being not only insufficlent but downright dangerous:

advanced technology applied to agriculture, industry, energy-conversion, and medicine has generated the environmental crisis in the first place. Our high-technology soclety is accused of having done more than any other to release toxic chemicals and radiation sources into our environment. Some environmentalists claim that even the ozone shield is becoming depleted. Allegedly, radloactive carclnogens have made preparation of food a lethal operation. Expert environmentalists testify in congressional hearings that even mother's milk is polsoned. The world has become diswally unsafe. 14

In the name of sheer survival, we are further warned that rising human expectations demanded by more and more people simply cannot be met by accelerating the rate of technological solutions. Growth of everything-above all, high technology--must come to a halt. According to Davit Brower, one of the root causes of the environmental crisis is a "growth ethic" that does not lead to increased well-being for the majority of people, but rather leads to increased oppression and alienation of the many, while the few get richer and suffer from bad consciences. 15 We ar 2 told that our goal must be a steady-state society, an ecostasis, a sustainable 
environmental quality. In short, for anyone except the blind and the immoral, an ecological crisis is simply self-evident. The short- and long-term solutions are a matter of simply making the right antitechnological choices immediately. The strategies are clearly dictated by our sense of moral obligation.

Having at last achieved an ecological crisis-consciousness, environmentalists have come of age. Other affluent Americans must be made to realize that our materialistic consumerism and careless technology reflect the values of a spoiled child. The adventuresome spirit of exploration with its new frontiers to conquer, its exultation in the vitality of growth, is at best adolescent. Fortunately for us a11, that ultimate symbol of devotion to techrologlcal mastery-the space program--signed its own death warrant when electronic wizardry: transmitted back to earth a sobering:vision of our isolated, finite, fragile planet. Our only reliable spaceship now is earth: a small, sick planet that we--her only friends--are morally obligated to heal and preserve for future generations.

So much for crisis-consclousness. Only by comprehending the climate of crisis generated by the ecology movement--its historical pedigree and underlying assumptions--can we expect to understand the reason why certain technological risks are dismissed as unacceptable.

THEMES AND ASSUMPTIONS UNDERLYING ENVIRONMENTALIST ISSUES

Environmentalist 11terature varies greatly, of course, in style and substantive content. When stripped of its rhetoric, however, the following themes and underlying assumptions recur.

(1) The first and most fundamental is that some vague, fragile "balance of nature" has been upset, if not irreversibly destroyed, by man's mindless drive toward mastery over nature by means of an ever-developing, encroaching technology.

(i) Closely connected with this notion of a balance of nature is a quasi-religious assumption that nature is in itself, or by derivation from a cieity, sacred. The implication is that nature is not only unspoiled or pure in its pristine, wilderness condition, but also endowed with certain inalienable rights which for man to violate or transgress would be immora1. I7 Human needs, consequently, should be stringently regulated and our social institutions restructured so that individual 1ffe-styles and reproductive cholces can be predetermined not to exceed prescribed, quantifiable 1imits. 
(j) Moreover, the quality of life must.cease to be a moving target, freely defined by individuals or elitists, and must now be made the dependent variable of earth's limited carrying capacity.

The cultural climate of crisis generated by the leaders and literature in the ecology movement, its historical pedigree and underlying assumptions about nature, man, and earth's limited carrying capacity naturally leads to the quasi-religious fervor and moral indignation which motivates much of the political oppositiun to nuclear technology and radioactive wastes. Arguments pro and con about radiation hazards from the fuel cycle, reactor satety, terrorist blackmal1, and weapons prollferation are secondary to the fountainhead of the entire controversy.

That is to say, a number of persons in our democratic society have made dramatically different value judgments about what constitutes a good society. Nuclear sclentists and engineers often contend that this energy-conversion technology has, at an excessive price, been made demonstrably safe and ecologically preferable to fossil combustion. But that assurance, says Irwin Bupp, is irrelevant. "The nuclear critic merely responds that he objects to the type of social environment that engineering or administrative 'success' implies." 8

If public opposition to the acceptability of risks from nuclear technology and radioactive wastes is to be adequately understood, then the historical and religious roots from which ecological assumptions derive their momentum must be understood, as well as current challenges to the prevailing crisisconsclousness.

\section{Ecology Themes and Assumptions: Historical Roots and Religious Influences}

A considerable body of literature derives from Lynn White's essay, "The Historlcal Roots of Our Ecologic Crisis." 18 It is generally regarded as the most Influent lal article stimulating religious/theological reflection on the man-technologyenvironment interrelation. His thesis is that the root cause of our desecration of nature and subsequent ecological crisis in the Western World must be traced to the Judeo-Christian eth1c. A number of theologians, conservatlonists, ecologists, and economists appear to have accepted this provocative thesis as an article of falth. 
Fundamental to that thesis is the assumption that religion and philosophy have direct ecological consequences, because what men think about nature greatly affects the way they act toward nature. White's objective in trying to show the direci connection between re+igious doctrines and the present ecological crisis is to propose an alternative Christian mindset. Briefly stated, his argument takes this form. Whereas animistic, pantheistic, and polytheistic religions of ancient and Eastern civilizations have inhibited man's technological domination over nature (because it was believed to be inhabited by deities or was itself divine), the radical monotheism of Western Judaism and Christianity has, in effect, desacralized nature, robbing it of divinity and thus destroying taboos against man's appropriation of nature for his own purposes.

Two Judeo-Christian doctrines that have been the most consequential are a monotheistic God and an athropccentric Creation. By emphasizing the dominion God has given man over nature, they have sanctioned an exploitative ethic.

"By destroying pagan animism, Christiantity made it possible to explo1t nature in a mood of indifference to the feelings of natural objects."
Professor White concludes, after lamenting modern man's "ecological destructiveness," that "Christianity bears a huge burden of guilt." 18

RELIGIOUS DOCTRINES FOSTERING EXPLOITATION OF NATURE

White developed his thesis as a result of observing that Ceylonese Buddhists building a road would not disturb or destroy a nest of snakes, but watted patiently until the snakes had departed of their own accord. That experience led him to contrast the Buddhist attitude of reverence toward nature with the Western religlous attitude of superfority and exploitation. The Judaic concept of creation that Christiantty inherited has taught man that "no item in the physical creation had any purpose save to serve man's purposes." 19

of all religions, Christianity is the most anthropocentric. In absolute contrast to paganism, Hinduism, Buddhism, and Taotsm (with the exception of Zoroastrianism), Christianity "not only established a dualism of man and nature but also insisted that $1 \mathrm{t}$ is God's will that man exploit nature for $\lambda$ is proper ends. "19

The source of this religious loctrine appears to be unambiguously stated in Genesis. Having created 
man, male and female, in his own image, God sald to them, "Be fruitful and multiply, and fiil the earth and subdue it; and have dominion over the fish of the sea and over the birds of the air and over every llving thing that moves upon the earth" (Gen. 1:28). Ecological critics of Christian tradition insist that God's mandate for man's "dominion and subjugation" of nature must be displaced by Eastern religious beliefs and attitudes.

White is dubious, however, about our adopting the man-nature view of Eastern religions as an antidote and solution to our ecologic crisis. Instead, he proposes St. Francis of Assisi, exemplifying self-sacrifice, as the patron saint of ecologists.

A number of other Western humanists have expressed a bias toward Taoist and Buddhist traditions by extolling virtues inherent in the Oriental precepts of quiescence and an adaptive approach to nature--e.g., the ethical philosophy of ahimsa (i.e., non-injury as a lifestyle in thought, wor 1 , and deed) ${ }^{20}$ and the concept of feng-shui, or geomancy, defined as "the art of adapting the residences of the living and the dead so as to cooperate and ha:monize with the local currents of cosmic breath." 21 Construction blends into the landscape; natural curves are preferred to stralght 11nes.
Yi-Fu Tuan, in h1s essay "Discrepancies between Environmental Attitude and Behavior: Examples from Europe and China," subtly refutes White's thesis about the power of religious attltudes to control behavior. There is a wide discrepuscy, he maintains, between the commonly accepted offlcial line on 0riental religious attitudes toward the environment and actual practice. He reviews the historical record and shows that gigantic transformations of the natural environment in Oriental civilizations were far from adaptive or geomantic. He cites cases of massive deforestation and erosion, of rice terraces and walled ctties, of large-scale engineering of marshes and rivers. As an example,
"By the Sung dynasty (A.D. 960- 1279) the demand for wood and charcoal as both household and industrial fuel had reached a level such that the timber resources of the country could no longer meet it; the result was the increasing substitution of coal for wood and charcoal. " 22

Other evidence also refutes White's thesis. Centuries before the advent of any Judeo-Christian doctrinal Influences, Plato's Critias lamented the deforestation and overgrazing of Attica. Since primitive times, agricultural people everywhere-Egyptian, Assyrian, Roman, Persian, Indian, Aztec, Buddhist--have cleared 
fields, dammed streams, killed predatory arimals, as weil as extirpated unwanted plant life.

Little historical evidence supports the contention that a Judeo-Christian ethic of exploitation has caused our alleged environmental crisis. Even less evidence indicates that a Taoist-Buddhist ecologlcal ethic of rature can be summoned to replace 1 t. In the view of Rene Dubos, White's theory that religious attitudes are responsible for a technologica11y-induced ecological crisis is "at best a historical halftruth." To the contrary,

". E erosion of the land, destruc-
tion of animal and plant species,
excessive exploitation of natural
resources, and ecological disasters
are not peculiar to the Judeo-
Christian tradition and to scien-
tific tect nology. At all times,
and all over the world, man's
thoughtless interventions into
nature have had a variety of
disastrous consequences or at
least have changed profoundly the
complexion of nature." 23

RELIGIOUS DOCTRINES FOSTERING SCIENCE AND TECHNOLOGY

The second idea developed from White's thesis is that there is a demonstrable connection between the Judeo-Christian ethic of exploitation and the development of Western science and technology. The idea is not original with White. Other Christian theologians earlier maintained that the comnection between technological development and biblical faith is more thar accidental. In 1954, Arend van Leeuwen extolled the gift of Christianity not only as a liberation from "the fetters of 'sacred' tradition," but also as "the renewixl of society in the direction of a truly secular and man-made order of life." 24 In 1965, Harvey Cox credited both biblical faith and the theology of Karl Barth for having dismissed myth and ontology with the result that "man's freedom to master and shape, to create and explore now reaches out to the ends of the earth and beyond." 25 These statements were quite popular before environmentalism had dispatched technology into 1 ts current state of disrepute.

As a historian especially knowledgeable in medieval technology, 26 White shares the basic premise of these theologians, namely, that "the victory of Christianity over paganism was the greatest psychic revolution in the history of our culure." Indeed, our implicit faith in perpet - 1 progress, unknown either to ireco-Roman antiquity or the Orient, cannot be understood apart from its roots in JudeoChristian teleology; i.e., the divinely-intended purpose of all creation. The fact that communists share it only confirms what is otherwise demonstrable: "that 
Marxism, like Islam, is a JudeoChristian heresy." 18

Since the Creator has made nature and man in His own image, the religious study of nature (natural theology) can reveal the divine mentality: In fact, what motivated such scientists as Galileo, Leibnitz, and Newton in the past to decode nature's symbol system was "to think God's thoughts after Him."18

Unfortunately, with the marrlage of sclence and technology a century ago, man acquired powers which have had such disastrous ecological effects that, says White, we now recogaize them to be "out of control." Whether people think that their technological attitudes are Christian is irrelevant; their basic values have not been displaced. Consequently, "we shall continue to have a worsening ecologic crisis until we reject the Christian axiom that nature has no reason for existence save to serve man. " 17

Arnold Toynbee has given strong support to White's contention. Based on his observation of modern religion in Fastern Asla and his book-knowledge of anclent Greek and Roman religion, he avers that the spread of monotheism "has removed the age-old restraint that was once placed on man's greed by his awe." Even where monotheism has never been establlshed, the monotheistic disrespect for nature has survived.

\begin{abstract}
"Japanese converts to Christianity have been few . . but the Christian attitude to nature, which continues to be the post-Christian attitude, has prevailed in Japan in defiance of the contrary Weltanschauung that is implicit in the Japanere people's religions, Shinto and Buddhism." 27
\end{abstract}

Since the revolution of 1868, and more vehemently still since World War II, "the Japanese have been fallowing the modern Western malpractice of exploiting nature, and they have been incurring the penalty." 28

Several writers have objected strongly to the White-Toynbee reductionism. Lewls Montcrief presents evidence that the Judeo-Christian tradition is only one of many cultural Eactors contributing to the alleged environmental crisis. He suggests that "the wide acceptance of such a simplistic explanation is at this point based more on fad than on fact." 28 To account for the alleged crisis as primarlly "a religlous problem" avoids several hard questions. 29 For example, why is it that science fiourished so vigorously in China, in ancient Greece, or in medieval Islam without any influence from Christianity? Why did Christian doctrines of God and Creation in Eastern Orthodoxy not 
produce the same science and technology developed by the Latin West? Since Christianity was dominant in the West from the fourth to the fourteench century, how does White exp1.n1n tie collapse of Poman

technology?

James Barr, from a detalled scrutiny of what the old Testament might have to do with pollution of the environment, maintains that the doctrines and legends of the JewtishChristian world in which sclence developed have obviously had an enormous influence upon it, along with everything else that went or. "But," he concludes, "to suppose that these doctrines not only influenced the rise of science but had an extremely vital and preponderating causal relation to it, seems just enormously improbab1e." 30

Thomas Derr puts the case succinctly: ". . . it would be careless indeed to run a direct line from Biblical thought to ecological disaster via disrespect for nature." 31 For Montcrief, Barr, and Derr, the cultural influences that have operated to develop science and technology have not been single or simplistic, but instead multiple and diverse. In direct contradiction to White's thesis, evidence suggests that environmental follies have occurred no matter what mankind's religious preconceptions have been--and even where sophisticated technology has not existed. In short, "to say that technological society is in a mess, and that therefore the fault must lie in the dominant rellgion, is to credit religion with too much power over culture and to forget how eas $11 y$ culture perverts religion." 31

\section{CHALLENGES TO ECOLOGY THEMES AND ASSUMPT IONS}

Lynn White's essay and others since then have taken for granted that an environmental crisis exists and that scientifically generated technology is the causal villain. The case for a crisis cannot be made by appealing to any religious preconceptions as the root cause. According to key themes and assumptions of environmentalists, the crisis is self-evident. But a number of challenges lead us to belleve that it is not.

Consider the first assumption. Among others, Gerald Feinberg and George Land have thoroughly discredited the concept of a balance of nature as it is commonly understood by environmentalists. When environmentalists clafm that some human activity or technology has upset a presumed balance of nature and that dire consequences are about to unfold, they are assuming as a scientific fact that some vaguely intuited pre-established harmony of creation--some cosmic 
Master Plan-has so arranged and fixed the components of nature within a certain unique condition that, if changed, a catastrophic immoral violation occurs.

To the contrary, says Feinberg, such an assertion strangely mingles fact with dublous moral judgment. "There are an infinite number of posstble 'balances of nature' rather than a unique one." 32 Because natural phenomena and living things exist in complex interrelations, changes in some components will result in adjustments made by others. When we human beings attach values to an older or to a newer set of natural conditions, and ther judge one more or less desirable than the other, ve do so because of the aesthetic or ethical priorities we have accepted. Rather than attesting to a scientific fact, we are instead making an aesthetic or moral value judgment. Certain environmental conditions, such as smog from auto emissions or ocean dumping of wastes, are undesirable not because they violate some sacred or unique balance of nature, but because we failed to think through the consequences or the alternatives before we created those conditions.

Felnberg offers this caution:

"I know of no case where anyone has made an even plausible argument that we are approaching an actual environmental disaster. I think that in the absence of such. a case, some environmentalists may, by their cries of doom, desensitize people suffictently so that when a real crisis can be scientifically demonstrated, no one will be listening to them." 32

What criteria ought we to use in fudging whether an environment is good for human beings? Feinberg observes that, when people begin to talk about their 1dea of a good environiient, it usually equates with the one they grew up in or most enjoyed in childhood. Very little thought has been given to useful criteria for deciding whether any environment, on a global scale, is good for everyone. Instead, a sma11 minority indignantly assert: largescale technology, especially its energy applications, has been the cause of environmental degradation.

What does the historical record show? Have people suffered from advanced technology, or from the lack of it? Those who express a nostalgic wish to return to the simpler, purer life of a hundred years ago would profit from reading otto Bettman's book, The Good old Days--They ware Terrible! ${ }^{33}$ As we condemn Detroit and auto emissions for making city alr unbreathable, let us not forget a New York with 150,000 horses in the streets and the emissions they produced. Let us recall the accepted waste-management standards: kitchen 
slops, coal soot, cinders, and other trash piled high on city sidewalks.

When the younger generation tells us that our rivers and lakes would be clean and potable if only they had not been befouled by profit-seeking corporate Industrialism, they might re-read some pages from history. Past civilfzations have handled human wastes with such primitive sewage practices that in many places water pollution was worse than it is today. During our entire existence on earth, the quantity or air pollution produced by mankind does not begin to equal the quantities of toxic gases and particulates spewed forth from just three volcanic eruptions:

Krakatau irt Indonesia In 1883, Mt. Katmai in Alaska in 1912, and Hekla in Iceland in 1947. Nature releases $L$ en times more carbon monoxide into the stmosphere than all the activities of man. 34

When consumer advocates go through their litany of technology-induced hazards in the biosphere, citing In. particular excessive radiation, pesticidal chemicals, or carcinogenic good additives, someone should restore a historical perspective to the mounting crescendos of fearful protest. Among others, Wlllam Lowrance reminds us of what a life without advanced technology applied to agriculture, medical care, and generating electricity was really like: spoiled food, impure water, boiling laundry kettles, and the backyard lye pot. People were polsoned from unknown chemicals in many natural/organtc vegetables. Women canned food with such preservatives as bortc actd and formalitehyde in hIgh concentrations. The mafor insecticide 75 years ago-sprayed on everything from apples to strawberries to grapes--was lead arsenate or "Paris green." Red food colorting was not red dye $\$ 2$ but lead chromate--a horror to day's blochemist. Fatal diseases were not leukemia or Hodgkins disease or subtle forms of cancer. They were pneumonia, influenza, tuberculosis. Average life expectancy was forty to fortyfive years at the turn of the century. More than $13 \%$ of all infants died before their first birthday. The leading antiseptic in homes and hospltals was corrostve carbolic acid. Today, as some worry about the disinfectant hexachlorophene in soap, why do they so easily forget the harsh carbolic acld it has replaced, and the surgical operations it has made safer? 35

Has our world become dismally unsafe because of science and technology? Have environmental hazards increased in fact, or only in our levels of perception? Lowrance puts the case we11:

We now have the luxury to worry about the subtle hazards which at 
one time, even if detected, would have been given only low priority beside the much greater hazards of the day. 35

Consider the second assumption. When certain environmentalists express revulsion for humankind as the supreme pollution of the earth, they are thereby exposing an ethical value system whose social consequences could prove to be far more catastrophic for human welfare than any alleged environmental degradation.

It is one thing to become fully conscious of, and apply a remedy to, the mischief that has been wrought by misapplications of poor technology by shortsighted and greedy human beings. It is quite another to make the value judgment that, because of this mischief, the environment has rights that can take precedence over the rights of living human beings to satisfy basic needs. The ethical priorities of Joseph Meeker are typical of an extreme, yet not uncommonly shared view: people are replaceable; the giant redwood trees and endangered species are not. Professor Meeker objects to any discussion of resource allocation, or population and pollution control, as these serve to maximize human welfare, without discussing at the same time "the welfare of plants and animals - . Other forms of life have equal rights to life with men." His value system is transparent in this statement: "It is not important that individuals survive; but it is important that as many species as possible survive." 36

Thomas Derr flatly rejects this ethical prioricy system in stern words: "Here we have the ethical fruttion of the idea of nature's 'rights' against human 1ife. Here we have a root of the incredible callousness of some ecologists who hold much existing human life rather cheap." When this callousness is buttressed by prophets of environmental doom, the harm done to ethical sensibilities is great--the few are driven to assure their own survival at the expense of the many. "Symptoms of this moral disease," Derr continues, "are already present among ecologists who urge the powerful nations to look to their own interests and let the hungry masses starve, so that world population may be reduced to more acceptable levels." Those who set such a high priority on their standard for environmental quality that they would deliberately starve living persons today are indeed championing a "new set of ecological values" and an unjustifiable "ecological ethic." 37

The poor at home and abroad express profound resentment when ecological "realists" recomnend a freeze on growth, anti-consumption, and selfdenial. Social justice and protection 
of the enviromment require a global policy that will undertake vigorous efiorts to meet Third and Fourth World needs for energy resources. Otherwise the leaders of the poor will justifiably reject ecology as their enemy, and pursue their national development without any concern for possible damage to global environment.

Consider the third assumption. The twin concepts of natural resource exhaustion and a fixed carrying capacity have both been rendered questionable. Rene Dubos states the case against resource exhaustion tersely: "I would say that there are no natural resources in the world; all that we call 'natural resources' are raw materials transformed by man." He offers three examples. First, agricultural land exists only where it has been transformed by human effort; new food production technologies are now being developed which will amount to "agriculture without soil." Second, our selection of mineral resources demonstrates that "a resource is not what is here, but what can be used by man for a certain goal." Although aluminum has existed on earth since the beginning of time, "it did not become a resource until this century when a technique for chemical separatIon was developed." His third example, energy, traces the development of myriad natural sources for energy-conversion. About the assumption that resources are limited and nearly exhausted, Dubos states Elatly: "Resources are always invented. "38

The case against a flxed carrylng capacity of the earth has been made by those who reject the "fixed pie" model of the world in favor of the "growing pie" model. 39 intil the living standard of poorer nations rises enough to satisfy their subsistence and security needs, the key to an ecologically sound planet, namely, a stable population level, will never be able to lock the door on an age-old enemy: wars over resources that could be used to improve standards of living and alleviate human misery. It is time we recognize the difference between undifferentiated growth for its own sake, and an organic development in which our ethical priorities are dictated by the basic needs of the world's poor for food, clothing, shelter, and a kind of security that does not depend on breeding more children than can be cared for. From historical experience with the Tennessee Valley Authority, we know how extensively electricity can improve basic living standards through refrigeration, medical health care facilities, sewage treatment, etc. Only electricity in reliable quantities can provide the minimum level of health and prosperity. In 
the case of nuclear techno] ngy, we are not talking about growth but replacement. Enriched uranium and plutonlum are proven resources for a demonstrably safe way of generating electricity.

Environrentalist priorities are not primartly, or necessarfly, ethical prioritieg. Excessive concern for the environment has been defended because of our obligation to future generations. From that view, radioactive wastes are characterized as a million-year risk that we are bequeathing to future generations in violation of our obligation to them. Consideration of the nature and scope of that obligation becomes highly pertinent to acceptable-risk criteria.

\section{Obligations to Future Generations: Acceptable Risk Criteria for Nuclear Wastes}

In one sense, our'present decade is unique and unprecedented. Prior to the early 1970's, except for some abstract generalizations, there were virtually no systematic ethical reflection and published discussion about the nature and scope of obligations that those now living have to future generations. ${ }^{40}$

Subsequent ethical discussions of responsibility to the future appear to have been evoked by, and restricted to, evaluations of biomedical research and potential technological applications, e.g., reproductive technologies (artificial insf ination and in vitro fertilization), genetic engineering (algeny, cloning, positive eugenics), fetal research, recombinant DNA molecular technology, population contro1, etc. ${ }^{41}$ These discussions. are Implicitly ethical assessments of risks and benefits. They address the problem of present generations reaping technological benefits that entall a legacy of risks or injury to future generations.

Risk/benefit assessment and costeffective analysis are fairly recent. ${ }^{42}$ Their ascendancy seems to derive from the pragmatic success of that managerial faith referred to at the outset of this study. One major difference between this generation and all its predecessors is that our increased knowledge of cybernetics has enormously extended our ability to know predictively the range of consequences of human activity, to envisage their implications on a global scale, and to understand why certain activities have potentially global effects. 
With all due respect to Malthus, this has not been the case in earlier generations. 43

Consequently, the concept of risks has been recently enlarged beyond those voluntarily accepted by individuals for occupational or personal benefits. Models for risk analysis have tended increasingly to predict, not present or local harmful events, but global catastrophes with a potential to affect future populations. A worst-case concept or an imaginary maximum credible accident seems unique to our present human condition. One ethicist regards the point of ethical departurs from this condition as a simple fact:

". . we now have a human community of planetary proportions. 'Mankind' is no longer principally an abstract notion. Mankind is a vibrant complex reality. There are actual relationships binding men and places and activities to each other, spanning the globe; and this is a new thing in the twentieth century." 2

Risk-assessment mode1s express what is radically novel about our present ethical situation and heightened sense of personal moral responsibility.

"For the first time in history, we have to live in a world entirely encompassed by human powers. This does not mean that the individual human being feels more powerful in himself. Far from it. But what he is surrounded by are other human powers, not tigers and not gods."2
In our new ethical situation, our legacy to future generations has assumed a critfcal importance.

ETHICAL PRINCIPLES PERTINENT TO THE LEGACY-OF-RISK QUESTION

Martin Golding and Daniel Callahan have taken up the general question of obligations to future generations under three headings: (1) the nature and basis of that obligation; (2) how to balance obligations to future generations against obligations to an existing generation; (3) ethical norms appropriate for any present decision having implications for the lives of future individuals and groups. 44

It is not an idle question to ask how we can possibly have obligations to those who do not even exist--those with whom we will not share a common life or the same social ideal or a similar conception of the good life. Callahan thinks that at least a theoretical basis for recognizing future claims can be found in the necessary biological link between generations, each in turn dependent upon the other: ". . later generations exist because of burdens assumed by earlier generations . . . To live at all is to be linked in an intricable way to the past and to be a determinant of the future. "41 We owe to future generations at least what we have been given by those who 
preceded us: namely, the posstbility of life and survival. The more distant generations become from our ability to know what to desire for them, or how to protect them from harm, the more justified we are in discounting any claims or obligations they have on the living. Golding writes:

\begin{abstract}
"If we have an obligation to distant future generations it is an obligation not to plan for them - . The more distant the generation we focus upon, the less 1ikely it is that we have an obligation to promote its good. We should be both ethically and practically well-advised to set our sights on more immediate generations and, perhaps, solely upon our immediate posterity. After all, even if we do have obligations to future generations, our obligations to immediate posterity are undoubtedly much clearer. $" 45$
\end{abstract}

Callahan insists, however, that there is a difference between positive obligations to enhance future lives, and negative obligations to avoid causing harm. His moral logic dictates: If present behavior induces hazards, then they must be avolded. The logic applies, he cautions, only when the hazards are established by proof. He also thinks it reasonable to suppose that--no matter how remote in time-future generations will share fundamental human soctal ideals: a w111 to life, basic nourishment and protection, Intelligence exercised by good minds, and some social-ethicalpolitical order. 46

The need to balance obligations to future generations with claims of the living requires the resolution of many ethical dilemmas about conflicting values, dutles, and rights. Callahan suggests this principle as a partial solution:
"One thing that can be said for the present generation over against future generations, is that they have existing rights: the right to life, liberty and the pursult of happiness (to choose one familiar formulation). They are here and the future generations are not. The cloisin of future generations agalnst is a conditional claim, in the sense that 1 tepends upon their existing to make the claim. That we know they will exist is enough to determine that their claim is not a fictitious one; but it is conditional in the sense that a number of conditions have to be fulfilled before the claim can be entered..."41
Be that as it may, the living do not have absolute priority of clains. Their claims do not extend to a "surplus exercise of rights which goes well beyond what is minimally or even moderately necessary for a decent human 1ife." 41 Individuals differ, to be sure, in their cholce of a valid and meaningful decency in their quality of life. An acceptable exercise of individual rights ought to be judged by whether it jeopardizes rights that future generations will claim, and that we now claim. 
On the basis of the kind of analysis conducted by Golding and Callahan, at least three ethical norms appear to govern any consideration of the acceptability of a legacy-of-risks to future generations:

(1) Those risks should not be Induced by an established, proven hazard that would jeopardize the very existence of future generations, immediate or remote.

(2) Those risks should not jeopardite the possibility of future generations to ererctse fundamental rights necessary for a moderately decent quality of life.

(3) Those anticipated risks should neither impose excessive costs, nor exact sacrifices of existing fundamental rights among the living, nor preempt choices of future generations by imposing a legacy with no options to change present decisions.

BIOETHICAL CRITERIA FOR AN ACCEPTABLE RISK-LEGACY FROM NUCLEAR WASTES

From a bioethical perspective, criteria for determining the acceptability of future risks from radioactive wastes should derive from the ethical norms which govern any legacy of risk. Alterations in our genetic constitution by genetic surgery and drastic engineering, or failure to provide for a sustainable population growth, both have a far more direct and potentially hazardous connection with prolonging the human species than risks from radioactive waste, public perception notwithstanding. An ethical methodology for assessing the acceptability of risks from radwastes must not only distinguish perceived risks from actual risks, but also give priority consideration to actual risks and costs imposed upon the living rather than to potential risks for future generattons.

In conformlty with the ethical norms outlined above, those who define acceptable risk-legacy criteria would have to establish whether the perceived hazard:

(1) is actual rather than imaginary;

(2) is so large and so permanent that it threatens the very existence of. immediate and even distant generations;

(3) deprives future generations of tleir fundamental rights to a decent quality of life;

(4) imposes excessive costs on the living;

(5) requires the living to sacrifice their fundamental rights 
to a moderately decent quality of life;

(6) preempts choices and forecloses options for future generations.

One of Callahan's recommendations about a method of thinking responsibly concerning the future is that we should not imaglne that future generations will be very dissimilar in their ideals and decision-making. Rather we should "take what we do know, and can reasonably project, and act accordingly." 41

Among futurists, those with most experience in methods of assessing future risks are economists and investors, who have devised a method of discounting future income as an objective process of (1) welghing degrees of risk and (2) comparing equivalent kinds of risk to judge which option yields the greater benefit (or reduction of risk) per unit of investment/expenditure. If Callahan's recommendation has mertt, two things are to be said about appropriating this method of discounting future income into bioethical methodology as a model for discount1ng future risk.

In the first place, burdened as it is with the uncertainties and expectations of a new cultural situation, ethical methodology requires already-proven, nonarbitrary processes of risk assessment. The invidious distinction between objective facts and subjective values has obscured the social necessity of ethical discourse for decision-makers. Goods which depend for their fulfillment on human activity are expressed in concrete, measurable, visible, audible, culturally significant forms. Rlsks exist only in relation to recognizable and measurably expressed goods. They are therefore amenable to assessment by some measuring process.

In the second place, the public character of dectsions affecting public health and safety require a visible method of judging the accountability of elected or appointed officials allocating public monies justly and equitably. Private persons have no a priori restrictions imposed upon their personal moral judgments concerning the value of a human life, their own or another's. But, by accepting a public trust, public officlals accept a priori restrictions to be just and equitable in the allocation of fixed, limited, exhaustible resources. Given the objective to maximize health and safety by the expenditure of financial resources, there is an ethical imperative to use a method that can (1) assess degrees of risk from any assumed hazard, (2) compare equivalent kinds of risk, and (3) measure 
the cost-effectiveness of one proposed reduction of risk to health vs another proposal. In the case of a legacy of future risks, if we do not use a proven method of measuring temporal variations in the cost-effectiveness of reducing present vs future risks, public officials could not be held accountable for their decisions about resource allocation.

\section{Conclusion}

The nature of the nuclear waste problem is neither unique nor unprecedented. We have always lived with toxic elements in our environment, and they have not been sequestered with the skill and planning applied to radwastes.

As an ethical imperative, criteria for acceptable risk must avoid two potential extremes. On the one hand, they must avoid capitulation to requirements for acceptability dictated by a vocal minority whose values and priorities neglect basic necessities of the many human beings now alive. On the other hand, they must avoid excessive preoccupation with imaginable risks to future generations of humans whose claim upon the intellectual and moral responsibility of existing persons has not yet been clearly def Ined.

Man does not live by safety alone. The ultimate challenge is to rediscover what else we live by. 


\section{References}

1. W. D. Rowe, "Development of Approaches for Acceptable Levels of Risk," Proceedings of Conference on Risk-Benefit Methodology, Asilomar Conference, Monterey, California, September, 1975.

2. G. Pickering, "Ethics of Technology," Proceedings of Conference on Technology, Values and Education, Terre Haute, Indiana: School of Technology Indiana State Univensity, May 1971, pp. 17-36.

3. A. Jonsen and L. Butler, "Public Ethics and Policy Makıng," Hastings Center Report 5 (4), 24 (Aug, 1975).

4. William S. Sahakian, Ethics: An Introduction to Theories and Problems (Barnes \& Noble, New York, 1974), pp. 1-7. Cf. William K. Frankena, Ethice (Prent1ce-Ha11, Inc., Englewood C1iffs, N.J., 1963).

5. H. D. Aiken, "Levels of Moral Discourse," In Reason and Conduct (Alfred Knopf, New York, 1962), pp. $69 \mathrm{ff}$.

For a distinction between moralist and 1deologist, see Aiken, "Morality and Ideology" In Ethics and Society, Richard T. DeGeorge, Ed. (Doubleday/ Anchor, Garden City, NY, 1966), pp. 149-172.

For an application of Aiken's four levels of moral discourse, cf. D. Callahan, Abortion: Low, Choice and Mora:itity (Macmillan, New York, 1970), pp. 321-27.

6. H. Jonas, "Technology and Respons1b1lity. Reflections on the New Tasks of Eth1cs," Social Reserach 40 (1), 31-54 (Spring, 1973).

7. A. Schweftzer, out of My Life and Thought (New York, 1933), p. 188.

8. I. C. Bupp and J.-C. Derian, "Nuclear Reactor Safety: The Twilight of Probability," Harvard BusineBs School Bulletin, 13 (March/April 1976).

9. R. Carson, The Silent Spring (Houghton Mifflin, Boston, 1962).

10. G. T. L. Land, Grow or Die: The Unifying Principle of Transformation (Random House, New York, 1973).

cf. "The Evolutlonary Cris1s," The Futumist $\vartheta$ (2), 10-17 (February, 1975).

11. A. Gibson, "Technology As Sacrament," The Ecumenist, 92-97 (Sept.-Dct., 1973).

12. P. R. Ehrlich, The Population Bomb (Ballantine, New York, 1968 and 1971), P. R. Ehrlich, A. H. Ehrlich, and J. P. Holdren, Human Ecology: Problems and Solutions (W. H. Freman, San Francisco, 1973), P. Ehr11ch, The End of Affluence: A Blueprint for Your Future (Ballantine, New York, 1974), D. Meadows, D. Meadows, et al., The Limits to Growth: A Report for the 
Club of Rome's Project on the Predicament of Mankind (Universe Books, New York, 1972).

13. G. Hardin, "The Tragedy of the Commons," Science 162, 1243-1248 (13 December 1968). Reprinted in Exploring New Ethies for Svivival: The Voyage of the Spaceship Beagle (Penguin, New York, 1972), pp. 250-64. Cf. J. B. Cobb, Is It Too Late: A Theology of Ecology (Bruce, Beverly Hills, 1972), Earth Might Be Fair, I. Barbour, Ed. (Prentice-Hall, Englewood Cliffs, 1972), and The Environmental Crisis, H. Helfrich, Ed. (Yale Univ. Press, New Haven, 1970).

14. W. O. Lowrance, Of Acceptable Risk (William Kaufmann, Inc., Los Altos, 1976), pp. $1 \mathrm{ff.}$ E. D. Gray in Proceedings of Nuclear Waste Management Conference, October, 1976 (Springfield, Va.: National Technical Information Service, 1976).

15. D. Brower, Sierra Club literature, cited in T. Derr, Ecclogy and Human Need (Westminster, Philadelphia, 1.973 and 1975), pp. $46 \mathrm{ff}$.

16. C. J. Glacken, "Man's Place in Nature in Recent Western Thought," in This Little Planet, M. Hamilton, Ed. (Charles Scribner's Sons, New York, 1970), pp. 163-20. Cf. also G. P. Marsh, Mon and Nature, D. Lowenthal, Ed. (Belknap Press of Harvard Univ. Press, Cambridge, Mass, 1965), Pp. 42-43.

17. H. P. Santmire, Brother Earth: Nature, God, and Ecology in Time of Crisis (Thomas Nelson and Sons, New York, 1970).

18. L. White, "The Historical Roots of Our Ecologic Crisis," Science 155 (1203-1207) (10 March 1967). Reprinted in L. White, Machino ex Deo (MIT Press, Cambridge, Mass., 1968), in Tize Enviromental Handbook, G. De Bell, Ed. (Ballantine, New York, 1970), and in Ecology and Religion in History, D. Spring and E. Spring, Eds. (Harper and Row Torchbook, New York, 1974), pp. 15-31.

19. L. White, "Continuing the Conversation," Westem Man and Environmental Ethics, I. Barbour, Ed. (Redding, Mass., 1973), p. 55.

20. Cf. J. Needham, Science and Civilization in China, Vol. II (Cambridge, 1956), p. 69. Cited in Ecology and Reiigion in History, n. 18 above.

21. H. Chatley, "Feng-Shui" in Enoyclopedia Sinica, S. Couling, Ed. (Shanghai, 1917). Cited by Y.-F. Tuan, "Discrepancies Between Environmental Attitude and Behavior: Examples from Europe and China," in Ecology and Religion in History, n. 18 above, p. 100 . 
22. Y.-F. Tuan, op. cit., pp. $99 \mathrm{ff}$.

23. R. Dubos, "Franciscan Conservation versus Benedictine Stewardship," $A$ God Within (Charles Scribner's Sons, New York, 1972), Reprinted In Ecology and Religion in History, pp. 114-136.

24. A. van Leeuwen, Christianity in World History (Charles Scribner's Sons, New York, 1965), pp. 419-20. (First Dutch edition, 1954.)

25. H. Cox, The Secular City (Macmillan, New York, 1965), p. 82.

26. I. White, Medieval Technology and Social Change (Clarendon Press, London, 1962).

27. A. Toynbee, "The Religious Background of the Present Environmental Criais," in International Joumal of Environmental Studies 3, 141-146 (1972). Reprinted in Ecology and Relizion in History, pp. 137-149.

28. I. Montcrief, "The Cultural Basis for our Environmental Crisis," Science 170, 508-512 (30 Oct. 1970). Reprinted in Ecology and Religion in History, pp. 76-90.

29. Ib1d. Cf. Derr, op. cit., pp. 28-33.

30. J. Barr, "Man and Nature: The Ecological Controversy and the 01d Testament," in Ecology and Religion in History, pp. 48-75.

31. Derr, op. cit., p. 32 .

32. G. Feinberg, "Long-Range Goals and the Environment," The Futurist, 241246 (Dec., 1971). G. L. Land, Grow or Die: The Unifying Principle of Transformation. Cf. n. 10 above.

33. 0. Bettman, The Good old Days--They Were Terriblel (Random House, New York, 1974).

34. J. J. McKetta, "The World Doesn't End Here!" (Council for Environmental Balance, Inc., Louisville, Ky., 1974). ". . 93\% of the Co comes from trees and greeneries ( 3.5 billion tons/yr). Only $7 \%$ comes from man (?70 million tons/yr)."

35. W. Lowrance, op. cit., pp. $7 \mathrm{ff}$.

36. Cited by Derr, op. cit., p, 85.

37. Ibid., pp. 85, 82 .

38. R. Dubos, "Reasons for Hope," In Finite Resources for a Human Future, I. Barbour, Ed. (Augsburg, Minneapolis, 1976), pp. 152-53.

39. H. Kahn, "Two Characteristic Current Views on Technological and Economic Growth," The Futurist, 335-38 (Dec. 1975) (adapted from a Hudson Institute Document). 
40. M. Golding, "Obligations to Future Generations, The Monist 56, 85-99 (Jan. 1972). He notes, after citing a reference to a previous article, "Ethical Issues in Biological Engineering," that "I know of no other explicit discussion of the topic."

Thomas Derr also notes, In preparing his chapter, "The Obligation to the Future," that, "judging from the literature I have explored I would risk the guess that nothing has been written about the bases of this obligation to our descendants in managing our environment," Ecology and Human Need, pp. 89-90.

41. D. Callahan, "What Obligations Do We Have To Future Generations?" American Ecclesiastical Review 164, 265-280 (Apri1, 1971). The works of Golding and Derr are cited in $\pi .40$ above.

42. J. Cohen, "Why Benefit-Risk Analysis?" Health Physios Society Midyear Topical Symposium, November, 1971. The Asilmar Conference of September, 1975 (cf. n. 1 above) was an indication of increasing interest in the methodology.

43. Callahan, op. cit., p. 267 (n. 41 above)

44. Callahan's essay is substantially a commentary on Golding's article.

45. Golding, op. c1t., pp. 97-98.

46. Callahan, op. cit., pp. 273-274.

$\mathrm{BW} / \mathrm{gw} / \mathrm{lmc}$ 


\section{Appendix}

The bloethical perspective adopted throughout this study represents a departure from that which is considered "mainstream" among current specialists in the area of bioethics. In their view, the major problems with which bloethics should deal are: abortion, death and dying, genetic engineering, human experimentation, behavior modification, etc. However, I think such problems are more properly the domain of biomedical ethics. By contrast, bloethics should concern problems which arise from, and gravitate around, the quality of life of the biosphere--considered as a total system of conditions affecting the public health and safety of living organisms, primarily human persons.

To address a relatively new set of recognizable problems, bioethics needs a more comprehensive methodology for

(1) formulating those problems and (2) devising adequate social structures and policies for dealing with them. We do not lack ethical norms; indeed, we have more than we know how to Implement coherently. The primary need is to formulate the problems about our common humanity under present global conditions and in a cultural climate of crisis in which an upward spiral of public attention to problems is directly connected with a downward spiral in a public understanding of those problems. A model for an adequate methodology is admittedly secondary, yet needed.

To that end, the attached design iilustrates the complexities of decision making. It is adapted from the models and rattonale offered by

1. E. Lasz1o, A Strategy for the Future: The Systems Approach to World Order (George Braziller, New York, 1974), pp. 144 ff.

2. M. Mesarovic and E. Peste1, Mankind at the Tuming Point: Second Report to the Club of Rome (Hutchinson, London, 1975), pp. $48 \mathrm{ff}$.

3. J. T. Hanford, "Systems Theory for Bioethics," Unpublished MS (1974). 


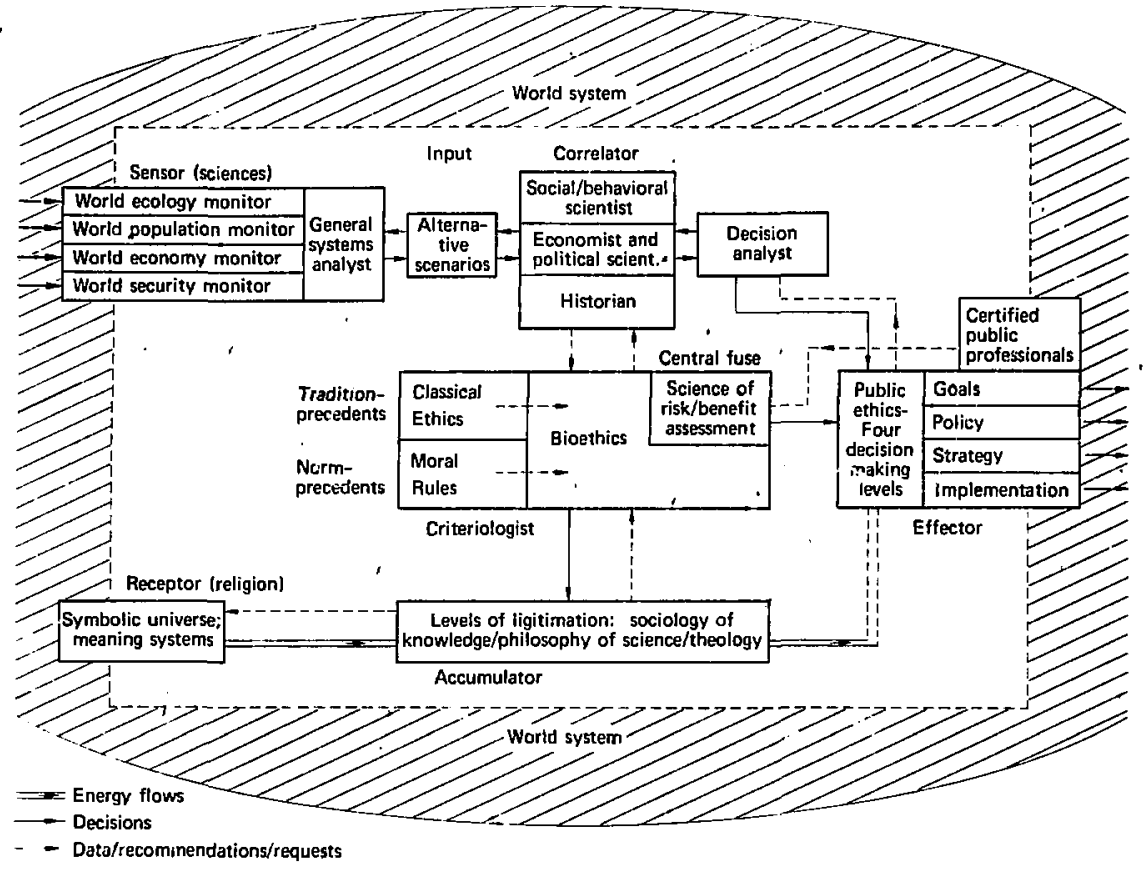

Fig. A.1. Design for a total-system bioethics. 